\title{
Species area-relationships and frequency - Floristical data analysis of 44 isolated woods in northwestern Germany
}

\author{
Dietmar Zacharias \& Dietmar Brandes \\ Botanisches Institut und Botanischer Garten der Technischen Universität, Arbeitsgruppe für Geobotanik, \\ Postfach 3329, D-3300 Braunschweig, FRG
}

Accepted 25.4.1990

Keywords: Frequency, Northwestern Germany, Rarity, SLOSS effect, Species-area relationship, Woodland islands, Woodland species

\begin{abstract}
44 isolated ancient woods (9,3-8579 ha) in southeastern Lower Saxony (northwestern Germany), where the Tertiary hilly country meets the Pleistocene plain, were investigated. Complete lists of 273 vascular plant species showing a more or less strong preference for woodlands were made for each wood including all the species of the groups Querco-Fagetea, Trifolio-Geranietea, Galio-Calystegietalia (selection of species) and Epilobietea. The majority of character species of woods show either a low or a high frequency, whereas fewer ones have medium frequencies. Most of the rarer species have their main occurrence in the larger woods. The number of species of all of the four groups increases with area of the wood and the correlation between the number of species and the log of area is related by a highly significant linear regression. Comparison of a single wood with two smaller woods of the same total area reveals that the two smaller woods on average have the greater number of wood species. Considering this and the fact that the rarer species have their main occurrence in the larger woods, when discussing questions of nature conservation a simple comparison of number of species and area is problematical.
\end{abstract}

\section{Introduction}

The relation between number of species and area has interested ecologists since the beginning of the century (Arrhenius 1921, 1923, Connor \& McCoy 1979). It has been discussed in terms of island biogeography (MacArthur \& Wilson 1967) and more recently, in respect to nature conservation (Higgs \& Usher 1980, Higgs 1981, van der Maarel 1981, Soulé \& Simberloff 1986). Considering landscape islands as one type of 'island situation', as defined by van der Maarel (1988), forests lying isolated in an agricultural landscape are of great interest. Species-area relationships based on data of woodland islands are discussed among others by Levenson (1981), Scanlan (1981), Peterken \& Game (1984), Harris (1984), Dzwonko \& Loster (1988, 1989) and Dzwonko (1989).

The number and frequency (rarity) of all species showing habitat preference for woodlands were investigated in 44 isolated ancient woods in southeastern Lower Saxony (northwestern Germany) (Zacharias \& Brandes 1989). Becher \& Brandes (1985) compared ancient and recent woods within the political borders of the city of Braunschweig. Janßen \& Brandes (1984) have 
discussed the species-area relation for Lower Saxony on the basis of complete lists of vascular plant species for particular areas. Based on dotgrid-maps of vascular plants Haeupler (1974) has analysed floristical data statistically for southern Lower Saxony.

\section{Study area}

44 isolated woods $(9,3-8579 \mathrm{ha})$ in the agricultural landscape which surrounds the city of Braunschweig (northwestern Germany) were investigated (Fig. 1,2). They are situated in a $50 \times 50 \mathrm{~km}^{2}$ area where the Tertiary hilly country meets the Pleistocene plain ( $80-320 \mathrm{~m}$ above sea level). The area consists of Mesozoic deposits often covered with loess. Climatic conditions show the region to be under subatlantic and subcontinental influence: the range of mean annual temperature of the region is $8.2-8.6^{\circ} \mathrm{C}$, the range of mean annual variations in air-temperature is

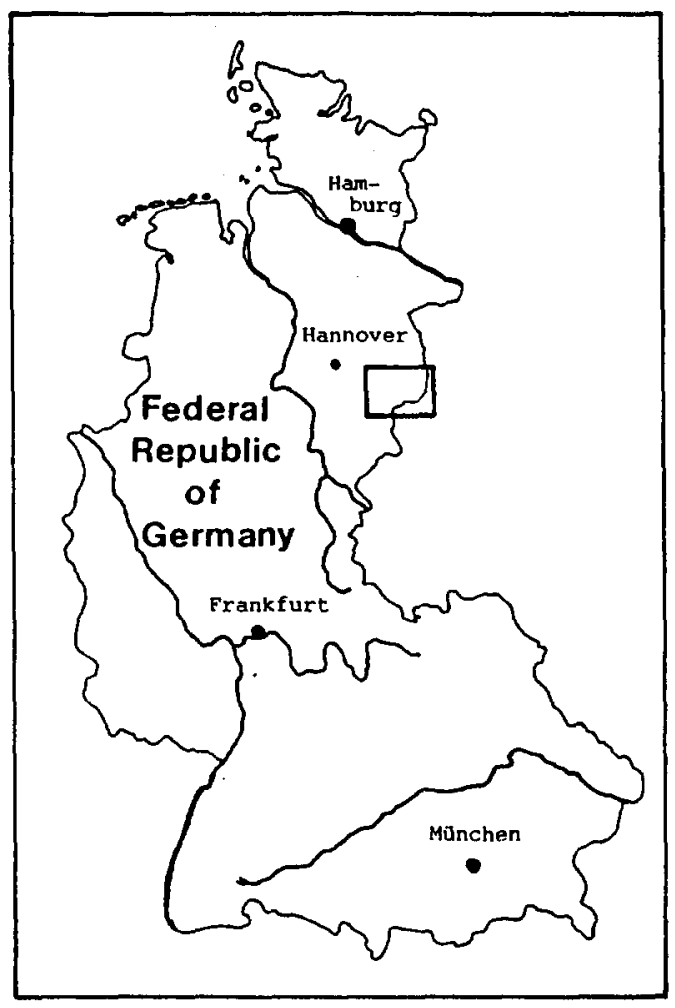

Fig. 1. Location of the investigation area.
$16.8-17.4{ }^{\circ} \mathrm{C}$ and the range of mean annual precipitation is $600-800 \mathrm{~mm}$ (Görges 1969).

Historical cartographic data (dating back to the middle of the 18th century) show all the investigated woodlands to be of ancient origin. The smallest one is situated within the city limits and is badly damaged as a result. The present shape of most of them does not differ from their shape of about 200 years ago.

Zonal vegetation is dominated by beech (Fagus sylvatica) whereas in azonal vegetation oakhornbeam forests with Quercus robur, Qu. petraea, Carpinus betulus and other tree species are predominant. In addition oak-hornbeam forests are supported by anthropogenic factors. The most important zonal types of woodland communities are 1) Galio odorati-Fagetum H. May $1964 \mathrm{em}$. (mesophilic conditions), 2) Hordelymo-Fagetum Kuhn 1937 (basiphilic conditions) and 3) LuzuloFagetum Meusel 1937 (acidophilic conditions). Covering smaller areas Carici-Fagetum Moor 1952 can be found on calcareous soils on more or less steep south facing slopes. An important community of azonal vegetation of the order of Fagetalia Pawl. 1928 is the Stellario-Carpinetum Oberd. 1957 occuring under wet conditions. Along streams the Carici remotae-Fraxinetum Koch 1926 ex. Fab. 1936 grows. Through anthropogenic influence Hordelymo-Fagetum and Carici-Fagetum have been replaced in some areas by oak-hornbeam forests of a floristical composition similar to the Galio-Carpinetum Oberd. 1957.

\section{Methods}

The distribution of all species showing a more or less strong preference for woodlands was registered. Their presence or absence in the 44 woods (nearly the whole wooded area in the region) was determined. Over a period of three years each wood was visited on at least three occasions. Special feature, such as margins and streams, were included. Complete lists of four selected groups of vascular plant species were made for each wood (Table 1).

The species-area relationship was investigated 


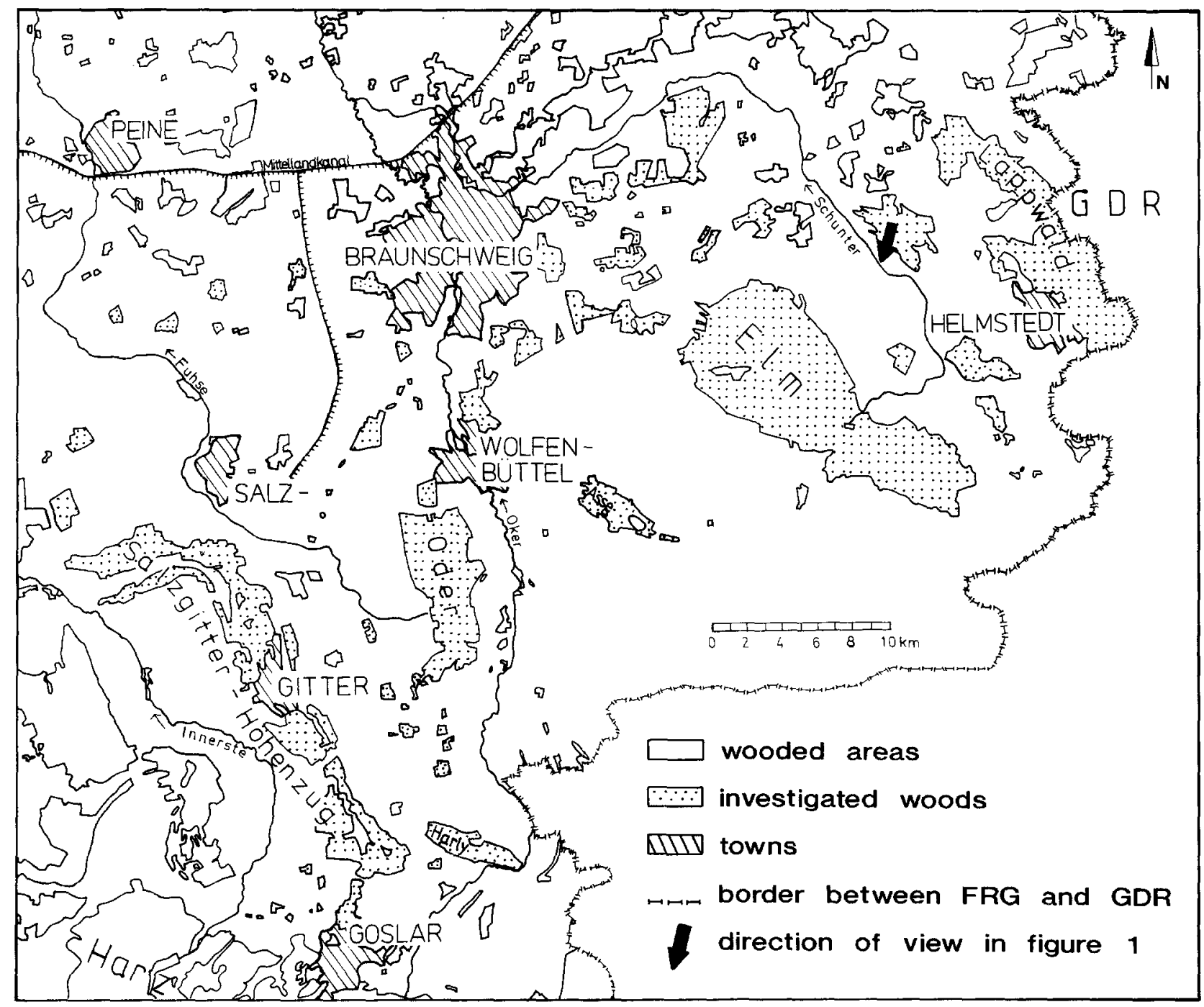

Fig. 2. The 44 isolated woods in the investigation area.

Table 1. Investigated groups of vascular plants.

\begin{tabular}{llc}
\hline $\begin{array}{l}\text { Group of character } \\
\text { species of class } \\
\text { or order }\end{array}$ & Habitat preference & $\begin{array}{l}\text { Number } \\
\text { of } \\
\text { species }\end{array}$ \\
\hline $\begin{array}{l}\text { Querco-Fagetea } \\
\text { Trifolio-Geranietea }\end{array}$ & $\begin{array}{l}\text { Wood } \\
\text { Thermophilous skirts } \\
\text { of the woods }\end{array}$ & 55 \\
$\begin{array}{l}\text { Galio-Calystegietalia } \\
\text { (selection of species) }\end{array}$ & $\begin{array}{l}\text { Nitrophilous skirts } \\
\text { of the woods }\end{array}$ & 27 \\
Epilobietea & $\begin{array}{l}\text { Cleared woodland } \\
\text { Woodland s.l. }\end{array}$ & 19 \\
\hline
\end{tabular}

using linear regression. The significance of differences between two population regression coefficients was tested by comparing the two slopes (Zar 1984). The number of species in relation to area for a number of single woods was compared with the data from a number of paired woods. The combined data were made up by adding the areas and the different species present for 44 randomly selected subsets of two woods. The frequency and the relationship between wooded area and species frequency is analysed taking into consideration only the data of the wood species of the class Querco-Fagetea. 


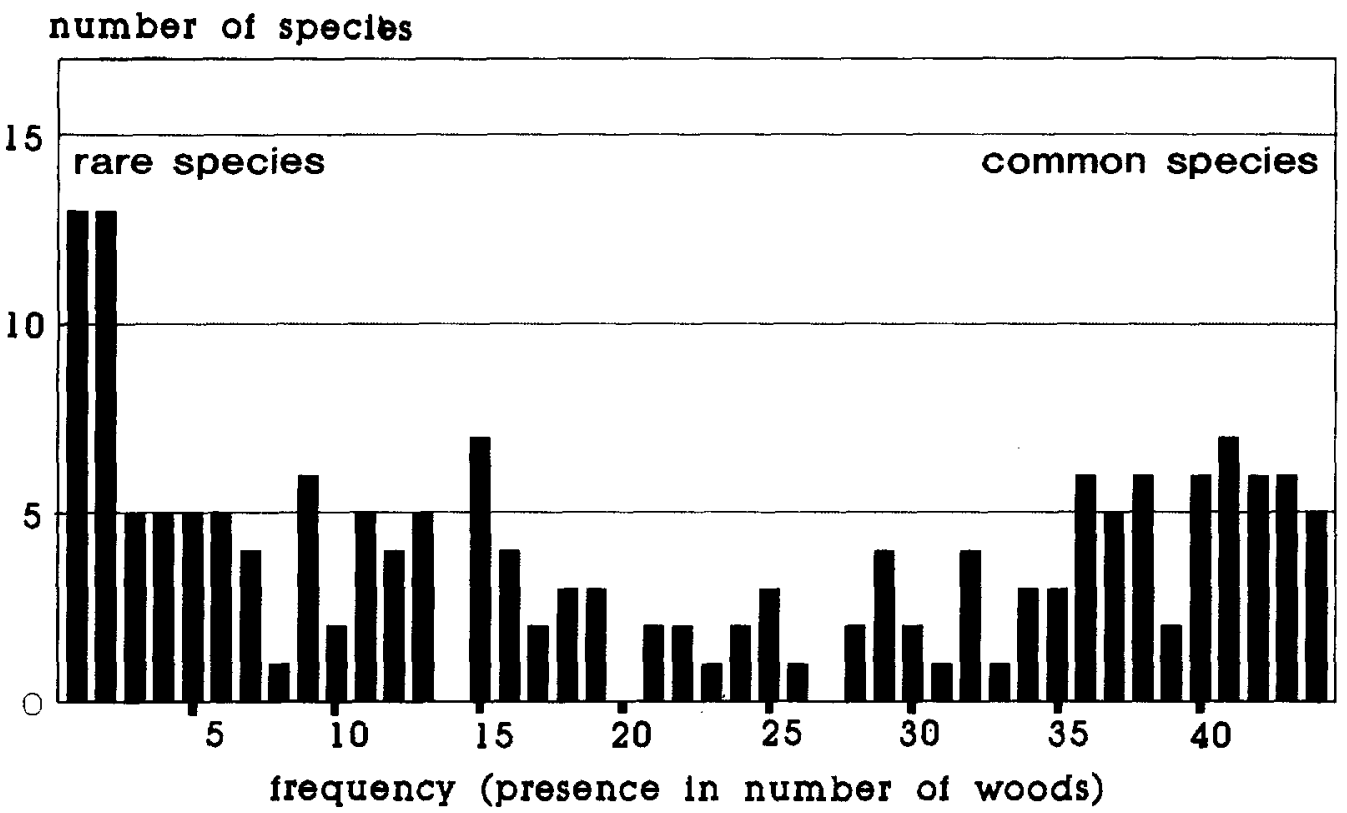

Fig. 3. Frequency of character species of woods based on presence/absence data.

\section{Results}

The majority of character species of woods show either a low or a high frequency, whereas fewer have medium frequencies (Fig. 3). The highest amount of species occurs in just one or two woods. Only five wood species could be found in all 44 woods. These are the two trees Fagus sylvatica and Carpinus betulus and the three herbs Anemone nemorosa, Rumex sanguineus and Stachys sylvatica (Fig. 4). The rarer species have their main occurence in the larger woods (Fig. 4).

The number of species for all groups increases with area and the relationship between number of species and $\log$ of area is related by a highly significant linear regression (Table 2). The number of Querco-Fagetea species and area show the closest correlation. The log species-log area model also indicades a significant correlation, although not as strikingly as does the species-log area model.

Species-log area data of series of single woods

Table 2. Species(S) - area(A) regressions for the investigated groups of vascular plant species.

\begin{tabular}{|c|c|c|c|c|}
\hline \multirow{2}{*}{$\begin{array}{l}\text { Group of character } \\
\text { species of class } \\
\text { or order }\end{array}$} & \multirow[t]{2}{*}{ Habitat preference } & \multicolumn{2}{|c|}{$S=c+z \log A$} & \multirow[b]{2}{*}{$\mathbf{r}$} \\
\hline & & $\mathrm{c}$ & $z$ & \\
\hline Querco-Fagetea & Wood & 13.77 & 30.22 & $0.78 *$ \\
\hline Trifolio-Geranietea & $\begin{array}{l}\text { Thermophilous skirts } \\
\text { of the woods }\end{array}$ & -10.35 & 9.69 & $0.72^{*}$ \\
\hline $\begin{array}{l}\text { Galio-Calystegietalia } \\
\quad \text { (selection of species) }\end{array}$ & $\begin{array}{l}\text { Nitrophilous skirts } \\
\text { of the woods }\end{array}$ & 9.55 & 3.74 & $0.48^{*}$ \\
\hline Epilobietea & Cleared woodland & 2.82 & 3.53 & $0.75^{*}$ \\
\hline \multicolumn{2}{|c|}{ The four groups together woodland s.l. } & 15.77 & 47.19 & $0.77^{*}$ \\
\hline
\end{tabular}

${ }^{*} \mathrm{p} \leq 0.001$ 


\section{the 44 woods in order of increasing area}

\section{species}

Anemone nemorosa

Carpinus betulus

Fagus sylvatica

Rumex sanguineus

Stachys sylvatica

Brachypodium sylvaticum

Poa nemoralis

Fraxinus excelsior

Carex sylvatica

Hedera helix

Lonicera periclymenum

Dactylis glomerata

Euonymus europaeus

Festuca gigantea

Rubus fruticosus agg.

Stellaria holostea

Milium effusum

Ranunculus ficaria

Crataegus laevigata

Quercus robur

Serophularia nodosa

Athyrium filix-femina

Circaea lutetiana

Polygonatum multiflorum

Corylus avellana

Acer pseudoplatanus

Sorbus aucuparia

Convallaria majalis

Lamiastrum galeobdolon

oxalis acetosella

Betula pendula

Galium odoratum

Viola reichenbachiana

Campanula trachelium

Prunus avium

viburnum opulus

Galium sylvaticum

Maianthemum bifolium

Acer campestre

Prunus spinosa

Melica uniflora

Primula elatior

Luzula pilosa

Cratarjus monogyna

Ranunculus auricomus agg.

Viola riviniana

Carex remota

Dryopteris carthusiana

Avenella flexuosa

Ribes uva-crispa

Tilia cordata

Arum maculatum.

Cornus sanguinea

Rosa canina

Pulmonaria obscura

Alnus glutinosa

pulus tremula

Adoxa moschatellina

Ranunculus lanuginosus

Lonicera xylosteum

Frangula alnus

Hieracium sylvaticum

Quercus petraea

Anemone ranunculoides

Ulmus glabra

Carex pilulifera

Impatiens noli-tangere

Acer platanoides

Dryopteris filix-mas

Dibes rubrum

Ribes rubrum

Sanicula europaea

Dryopteris dilatat

Phyteuma spicatum

Gagea lutea

Melica nutans

Rhamnus catharticus

Corydalis cava

Allium ursinum

Paris quadrifolia

Ligustrum vulgar

Lilium martagon

Myosotis sylvatica

Listera ovata

Lathyrus vernus

Prunus padus

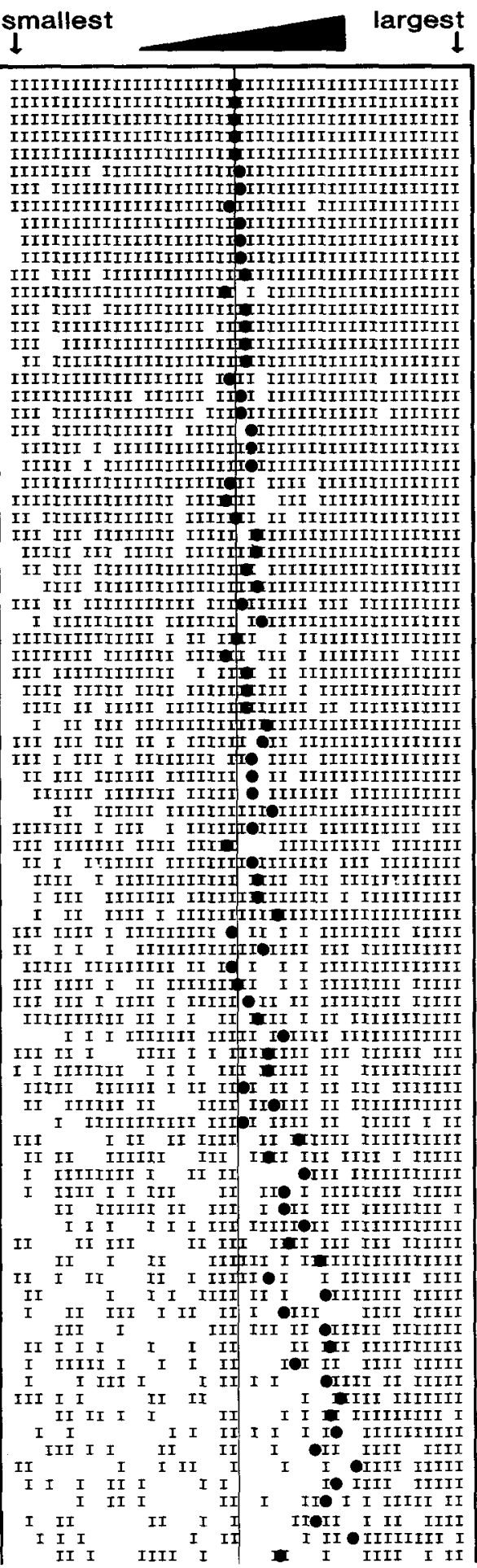

frequency

common

Fig. 4. The relationship between wooded area and species frequency of character species of woods. 


\section{the 44 woods in order of increasing area}

\section{species}

Humulus lupulus Gagea spathacea Hepatica nobilis Leucojum vernum

Epipactis helleborine agg.

Potentilla sterilis

Bromus benekenii

Daphne mezereum

Malus sylvestris

Luzula luzuloides

Pinus sylvestris

Hordelymus europaeus

Neottia nidus-avis

Clematis vitalba

Rosa corymbifera

sorbus torminalis

vaccinium myrtillus

pteridium aquilinum

Lathraea squamaria

aconitum vulparia

Aconitum vulparia

viola mirabilis

Vinca minor

Chrysosplenium alternifolium

Equisetum sylvaticum

Gymnocarpium dryopteris

Calamagrostis arundinacea

Tilia platyphylos

orchis purpure

Stellaria nemorum

Festuca heterophylla

Aquilegia vulgaris

Carex digitata

Hypericum montanum

Cephalanthera damasonium

Cephalanthera damasc

Festuca altissina

Ranunculus nemorosus

Asarum europaeum

Veronica montana

Ulmus minor

Epipactis purpurata

Epipactis microphylla

Buglossoides purpurocaeruleum

Actaea spicata

Rosa micrantha

Chrysosplenium oppositifolium Carex brizoides

Corydalis intermedia

Pyrola minor

phyteuma nigrum

Lysimachia nemorum

Ilex aquifolium

Thelypteris limbosperma

Helleborus viridis

Platanthera chlorantha

Orthilia secunda

Carex montana

Carex strigosa

Cephalanthera longifolia

Equisetum telmateia

Pyrus communis

Porus remota

Cypripedium calceolus

Equisetum hyemale

Equisetum hy

Ribes nigrum

Thelypteris phegopteris

U1mus laevis

Berberis vulgaris

Cephalanthera rubra

Hypericum pulchrum

Epipactis atrorubens

Polypodium vulgare

Polygonatum verticillatum

Platanthera bifolia

Rosa arvensis

Rosa elliptica

Campanula latifolia

Gagea minima

Gagea mi

Melittis melissophyllum

Potentilia alba

rpioides

Epipogium aphyllum

Circaea alpina

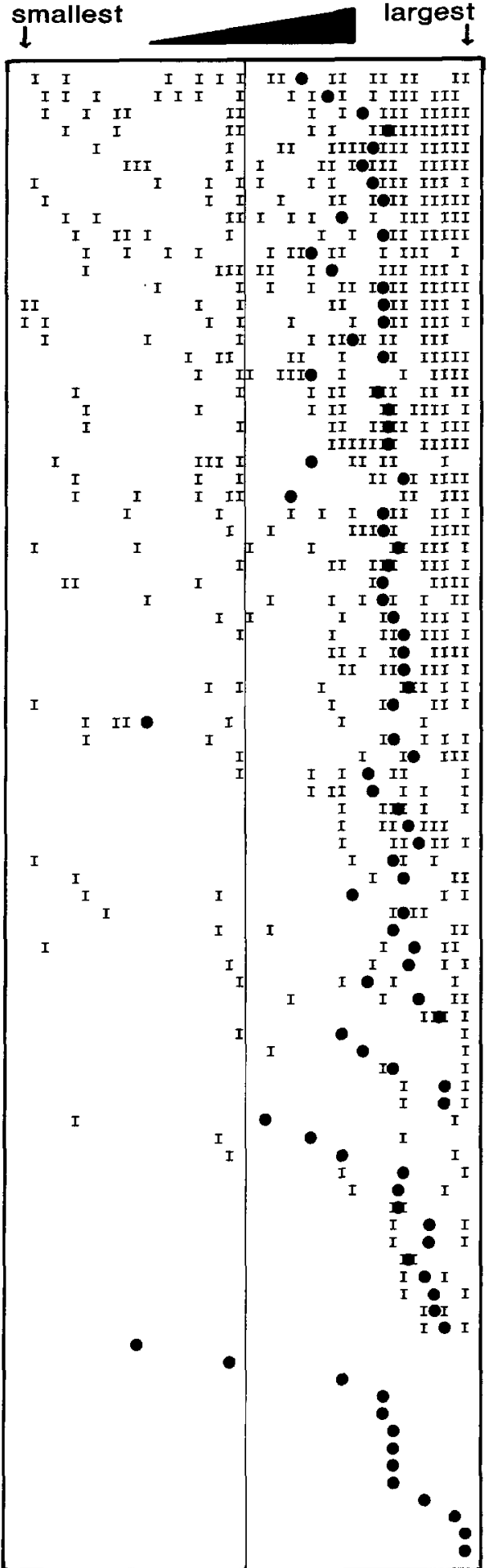

frequency

17
17 


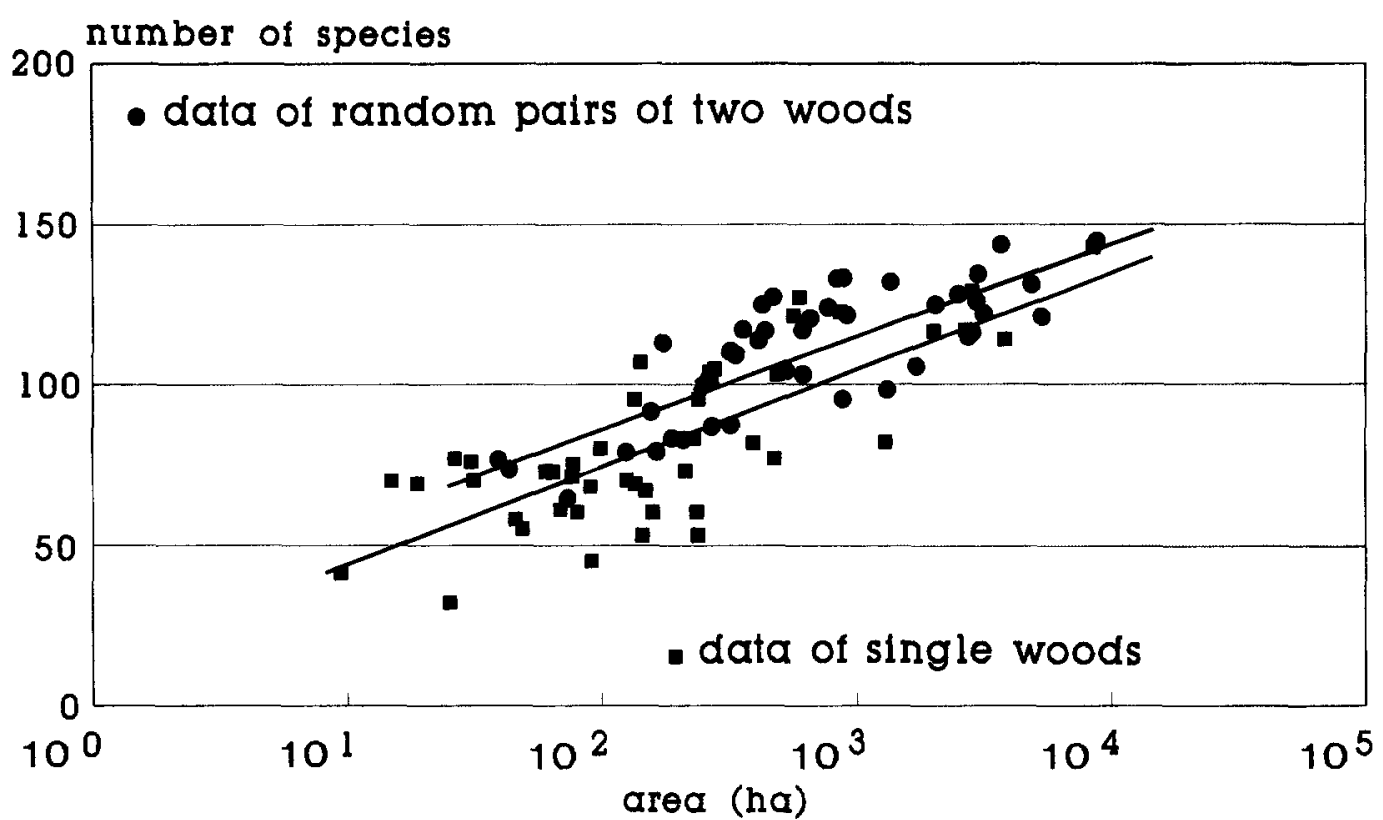

Fig. 5. Comparison of the relationship between number of character species of woods and area between series of single woods and for series of random pairs of woods.

and series of paired woods are shown in Fig. 5. Linear regression for the single woods is given in Table 2. For the series of two woods it is $\mathrm{S}=27.54+29.26 \mathrm{~A}(\mathrm{r}=0.88, \mathrm{p} \leq 0.001)$. Comparision of the two regression lines show significant differences in their slope $(t=2.14$, $\mathrm{p} \leq 0.05, \mathrm{n}=81$ ). More species are expected to be found in two smaller woodland islands than in a single large one of the same total area.

\section{Discussion}

The floristic data reveals considerable variation among the 44 woods, each wood having its own particular flora. The localities of some species have been known since 1652 (Chemnitius 1652, Brandes 1984) e.g. the recently very rare Melittis melissophyllum and Potentilla alba, others have disappeared in recent years. Many of the species registered by us have been found to show a preference for ancient woods in other regions of Europe (Hermy \& Stieperaere 1981, Peterken 1981, Peterken \& Game 1984, Kubikova 1987, Dzwonko \& Loster 1988, Dzwonko 1989). All of the 44 woods show a higher number of wood species that one would expect to find in recent woods (Peterken \& Game 1984, Becher \& Brandes 1985, Dzwonko \& Loster 1988, Dzwonko 1989, Hermy 1989). We found corresponding to the results of Dzwonko \& Loster (1989) a frequency distribution with the rare species forming the highest peak and the medium frequencies lying in a trough for wood species in woodland islands. The same type of frequency distribution has been found analysing complete species lists of 14 isolated plots in forest meadows (Zacharias, Janßen \& Brandes 1988). Many of the rarer species having their main occurrence in the larger woods are near the edge of their geographical range e.g. Cephalanthera damasonium, Epipactis microphylla, E. purpurata, Buglossoides purpurocaerulea, Hypericum montanum and Viola mirabilis (Haeupler \& Schönfelder 1988). Deshaye \& Morisset (1989) found that on real islands of the Hybrides Archipelago occasional and rare species mostly occured only on large islands. In woodlands of the Western Carpathian foothills 20 of the 56 rare species occur only in the large woods (Dzwonko \& Loster 1989), whereas 
Simberloff \& Gotelli (1984) and Game \& Peterken (1984) found no species to be confined to large woods.

Using the species-log area model a significant linear regression between the species number and the log of area for a wide range of wood areas (0.008-8579 ha) was obtained (Table 2 and Fig. 5, Peterken \& Game 1984, Dzwonko \& Loster 1988). Taking into consideration only the woody plant species Levenson (1981) was able to show that if disturbance or other factors become very important the species-area relationship ceases to be capable of predicting the number of species as a function of woodland size.

Deshaye \& Morisset (1989), discussing the SLOSS effect (Single Large Or Several Small reserves), showed that on real islands in the Hybrides Archipelago there are more species on a single large island than on several small ones of the same total area (if that area is smaller than 12 ha). But in fact one can also find more species on two small islands than on a single large one of the same area (Simberloff \& Abele 1976, Higgs \& Usher 1980, Higgs 1981). Looking upon woodland islands several authors found corresponding results: e.g. Järvinen (1982), Game \& Peterken (1984), Simberloff \& Gotelli (1984), Dzwonko \& Loster (1989). Our results show that Cole's (1981) major conclusion that large refuges will preserve more species than a series of smaller ones with the same area, is not true in the case of wood species in isolated woods considered as a type of landscape island.

For nature conservation it is important to know whether reserves should be large or small. Discussing reserve selection strategies Game \& Peterken (1984) focus on this question using woodlands of Central Lincolnshire, England as an example. We have shown that there are more species to be expected in two smaller woods than in a single one with the same area, while on the other hand, rarer species have their main occurrence in the larger woods. This makes clear that a simple comparison of number of species and area is not useful when discussing questions of nature conservation. It is also important to consider particular species, especially their habitat preference and rarity, as Becher \& Brandes (1985) and Soulé \& Simberloff (1986) have already pointed out.

Employing the record of the "floristical status quo' it will become possible to answer the following questions: 1) is there an interchange of species between woodland islands? and 2) what can we say about constancy of number of woodland species in relation to area in the course of time?

\section{Acknowledgements}

We would like to thank Mr. Roger Hicks for helping us to translate the manuscript.

\section{References}

Arrhenius, O. 1921. Species and area. J. Ecol. 9: 95-99.

Arrhenius, O. 1923. On the relation between species and area - a reply. Ecology 4: 90-91.

Becher, R. \& Brandes, D. 1985. Vergleichende Untersuchungen an städtischen und stadtnahen Gehölzbeständen am Beispiel von Braunschweig. Braunschw. Naturk. Schr. 2: 309-339.

Brandes, D. 1984. Die Flora von Braunschweig um 1650 im Spiegel des 'Index plantarum' von Johann Chemnitius. Braunschw. Naturk. Schr. 2: 1-18.

Chemnitius, J. 1652. Index plantarum circa Brunsvigam trium ferè milliarum circuitu nascentium cum appendice iconum. Brunsvigae. (Reprint 1982 by Verlag J. Cramer. Braunschweig).

Cole, B. J. 1981. Colonizing abilities, island size, and the number of species on archipelagoes. Am. Nat. 117: 629-638.

Connor, E. F. \& McCoy, E. D. 1979. The statistics and biology of the species-area relationship. Am. Nat. 113: 791-833.

Deshaye, J. \& Morisset, P. 1989. Species-area relationships and the SLOSS effect in a subarctic archipelago. Biol. Conserv. 48: 265-276.

Dwzonko, Z. 1989. The number and distribution of woodland vascular plant species in small forest islands on the Carpathian foothills. Stud. Plant Ecol. 18, pp. 67-68.

Dwzonko, Z. \& Loster, S. 1988. Species richness of small woodlands of the western Carpathian foothills. Vegetatio 76: 15-27.

Dzwonko, Z. \& Loster, S. 1989. Distribution of vascular plant species in small woodlands on the West Carpathian foothills. Oikos 56: 77-86.

Ehrendorfer, F. 1973. Liste der Gefäßpflanzen Mitteleuropas, 2. erw. Aufl. Gustav Fischer Verlag, Stuttgart. 
Game, H. \& Peterken, G. F. 1984. Nature reserve selection strategies in the woodlands of Central Lincolnshire, England. Biol. Conserv. 29: 157-181.

Görges, H. 1969. Forstliche Wuchsbezirke in Niedersachsen. N. Arch. f. Nds. 18: 27-45.

Haeupler, H. 1974. Statistische Auswertung von Punktrasterkarten der Gefäßpflanzenflora Süd-Niedersachsens. Verlag Erich Goltze, Göttingen. (Scripta Geobotanica 8).

Haeupler, H. \& Schönflder, P. 1988. Atlas der Farn- und Blütenpflanzen der Bundesrepublik Deutschland. Eugen Ulmer. Stuttgart.

Harris, L. D. 1984. The fragmented forest. The University of Chicago Press, Chicago.

Hermy, M. 1989. Former land use and its effect on the composition and diversity of woodland communities in the western part of Belgium. Stud. Plant Ecol. 18, pp. 104-105.

Hermy, M. \& Stieperaere, H. 1981. An indirect gradient analysis of the ecological relationships between ancient and recent riverine woodlands to the south of Bruges (Flanders, Belgium). Vegetatio 44: 43-49.

Higgs, A. J. 1981. Island biogeography theory and nature reserve design. J. Biogeogr. 8: 117-124.

Higgs, A. J. \& Usher, M. B. 1980. Should nature reserves be large or small?. Nature 285: 568-569.

Järvinen, O. 1982. Conservation of endangered plant populations: single large or several small reserves? Oikos 38 : 301-307.

Janßen, Ch. \& Brandes, D. 1984. Struktur und Artenvielfalt von Randzonen der Großstädte. Dargestellt am Beispiel von Braunschweig. Braunschw. Naturk. Schr. 2: 57-97.

Kubikova, J. 1987. Cultivated forest stands in Central Bohemia, their floristic composition and history. Martin Luther Univ. Halle Wittenberg: Wiss. Beitr. 1987/46 (P 31): $155-165 \mathrm{~d}$.

Levenson, J. B. 1981. Woodlots as biogeographic islands in South-eastern Wisconsin. In: Burgess, R. L. \& Sharpe, D. M. (eds.), Forest island dynamics in man-dominated landscapes, pp. 13-39. Springer, Berlin.

MacArthur, R. H. \& Wilson, E. O. 1967. The theory of island biogeography. Princeton University Press, Princeton.
Oderdorfer, E. 1987. Süddeutsche Wald- und Gebüschgesellschaften im europäischen Rahmen. Tuexenia 7: 459-468.

Peterken, G. F. 1981. A method for assessing woodland flora for conservation using indicator species. Biol. Conserv. 6: 239-245.

Peterken, G. F. \& Game, M. 1984. Historical factors affecting the number and distribution of vascular plant species in the woodlands of Central Lincolnshire. J. Ecol. 72: 155-182.

Scanlan, M. J. 1981. Biogeography of forest plants in the prairie-forest ecotone in western Minnesota. In: Burgess, R. L. \& Sharpe, D. M. (eds.), Forest island dynamics in man-dominated landscapes, pp. 97-124. Springer, Berlin.

Simberloff, D. \& Abele L. G. 1976. Island biogeography theory and conservation practice. Science NY 191: 285-286.

Simberloff, D. \& Gotelli, N. 1984. Effects of insularisation on plant species richness in the prairie-forest ecotone. Biol Conserv. 29: 27-46.

Soulé, M. E. \& Simberloff, D. 1986. What do genetics and ecology tell us about the design of nature reserves? Biol. Conser. 35: 19-40.

van der Maarel, E. 1981. Biogeographical and landscape ecological planning of nature reserves. In: Proc. Int. Congr. Neth. Soc. Landscape Ecol., pp. 227-235. Pudoc, Wageningen.

van der Maarel, E. 1988. Vegetation dynamics: patterns in time and space. Vegetatio 77: 7-19.

Zacharias, D. \& Brandes, D. 1989. Floristical data analysis of 44 isolated woods in northwestern Germany. Stud. Plant Ecol. 18, pp. 278-280.

Zacharias, D., Janßen, Ch. \& Brandes, D. 1988. Basenreiche Pfeifengras-Streuewiesen des Molinietum caeruleae W. Koch 1926, ihre Brachestadien und ihre wichtigsten Kontaktgesellschaften in Südost-Niedersachsen. Tuexenia 8 55-78.

Zar, J. H. 1984. Biostatistical analysis, 2nd edn. PrenticeHall, Englewood Cliffs, NJ. 